\title{
Onoma 54
}

Journal of the International Council of Onomastic Sciences

ISSN: 0078-463X; e-ISSN: 1783-1644

Journal homepage: https://onomajournal.org/

\section{Given names of Russian-speaking children born in Finland between 2000-2018}

DOI: 10.34158/ONOMA.54/2019/11

\section{Ksenia Eskola}

University of Helsinki

Department of Finno-Ugrian and Scandinavian Studies

PL 3

00014 Helsingin yliopisto

Finland

ksenia.eskola@helsinki.fi

\section{Lasse Hämäläinen}

University of Helsinki

Department of Finno-Ugrian and Scandinavian Studies

PL 3

00014 Helsingin yliopisto

Finland

lasse.j.hamalainen@helsinki.fi

To cite this article: Eskola, Ksenia \& Hämäläinen, Lasse. 2019. Given names of Russian-speaking children born in Finland between 2000-2018. Onoma 54, 197-217. DOI: 10.34158/ONOMA.54/2019/11

To link to this article: https://doi.org/10.34158/ONOMA.54/2019/11

(C) Onoma and the authors.

Given names of Russian-speaking children born in Finland between 2000-2018

Abstract: This article examines the given names of the Russian-speaking minority in Finland. The data include names of all the 9,459 children registered as native Russian speakers born in Finland between the years 2000-2018. These names 
are analysed both quantitatively and qualitatively, dividing them into categories of Finnish, Russian, and international names. The largest number of boys' names are Russian, of girls' names international. The most popular given names during the period were Daniel and Sofia. Of the children, 35\% received more than one given name; second and third given names being mostly Finnish or international. There are also some notable regional differences in name giving. Russian names are given more often in areas where the density of Russian-speaking population is high. Overall, given names of Russian-speaking children in Finland are a diverse mixture of Russian, Finnish and international naming fashions and traditions. They can reveal something about the parents' different relations to their linguistic and ethnic background.

Keywords: Given names, personal names, linguistic minorities.

\section{Les prénoms des enfants russophones nés en Finlande entre 2000 et 2018}

Résumé : Cet article examine les prénoms de la minorité russophone en Finlande. Les données comprennent les prénoms des 9459 enfants enregistrés comme des locuteurs natifs de russe nés en Finlande entre 2000 et 2018. Ces prénoms ont été analysés de façon quantitative et qualitative par la catégorisation en prénoms finlandais, prénoms russes et prénoms internationaux. Les prénoms donnés le plus souvent pendant cette période étaient Daniel et Sofia. Parmi les enfants examinés, $35 \%$ ont reçu deux ou trois prénoms ; la majorité des deuxièmes et troisièmes prénoms étaient finlandais ou internationaux. Il existe également des différences régionales dans les prénoms donnés. Les prénoms russes ont été donnés plus souvent dans les régions où la densité de la population russophone est élevée. Dans l'ensemble, les prénoms des enfants russophones en Finlande constituent une combinaison variée des traditions russe, finlandaise et internationale. Ces prénoms peuvent offrir des informations sur le rapport des parents vis-à-vis de leur milieu linguistique et ethnique.

Mots-clés : Prénoms, noms personnels, minorités linguistiques.

\section{Vornamen von in Finnland geborenen russischsprachigen Kindern 2000-2018}

Zusammenfassung: Dieser Artikel behandelt die Vergabe von Vornamen bei der russischsprachigen Minderheit in Finnland. Das Korpus besteht aus den Namen aller 9459 Kinder, die zwischen 2000 und 2018 von Eltern mit Russisch als Muttersprache vergeben wurden. Diese Namen werden sowohl quantitativ als auch qualitativ untersucht, indem sie in die Kategorien finnische, russische und internationale Namen unterteilt werden. Jungen erhielten am häufigsten russische, Mädchen internationale Namen. Die populärsten Namen während des untersuchten Zeitraums sind Daniel und Sofia. 35\% erhielten mehr als einen Namen, Zweit- und Drittnamen waren mehrheitlich finnisch oder international. Es existieren auch einige bemerkenswerte regionale Unterschiede. Russische Namen werden häufiger in Regionen vergeben, die einen hohen Anteil an muttersprachlich russischsprachiger Bevölkerung aufweisen. Im Ganzen stellen die an russischsprachige Kinder vergebenen Namen eine facettenreiche Mischung von russischen, finnischen und internationalen Namensmoden und Traditionen dar. Sie können Aufschluss darüber geben, wie unterschiedlich Eltern zu ihrem linguistischen und ethnischen Hintergrund stehen.

Schlüsselbegriffe: Vornamen, Personennamen, linguistische Minoritäten. 


\title{
Given names of Russian-speaking children born in Finland between 2000-2018
}

\author{
KSENIA ESKOLA AND LASSE HÄMÄLÄINEN
}

\section{Introduction}

The world is becoming more and more global due to increasing migration and developing communication technologies. Cultural differences between countries are diminishing in many ways (e.g. Gerritzen 2006). Personal naming practices, on the other hand, still vary greatly between different countries and cultures (Alford 1988; Lawson 2016). Therefore, personal names often convey something about the ethnic, linguistic, religious and other cultural background of their bearers. They preserve cultural heritage, but they might also expose their bearers for prejudices and discrimination, especially if they belong to a minority population (e.g. Pennesi 2016; Aldrin 2017). One example of such a group is the Russian-speaking population in Finland.

As neighbouring countries, Finland and Russia have a long shared history with several twists and turns. Before becoming independent, Finland was an autonomous part of the Russian Empire from 1809 to 1917. During the Second World War, Finland and the Soviet Union fought two wars, the Winter War in 1939-40 and the Continuation War in 1941-44. Finland retained its independence, but the Soviet Union and Russia have had a remarkable influence on its politics, especially during the Cold War (Singleton 1998).

During these last two centuries, a Russian-speaking minority has lived in Finland. It has grown rapidly since the dissolution of the Soviet Union: in 1991 they numbered 6,562, but already in 2018 there were 79,225, making $1.4 \%$ of Finland's population. They are the third largest linguistic group in Finland, following Finnish (88\% of the population) and Swedish (5.2\%). Most of the Russian-speaking population is located in the largest cities and in Eastern Finland, near the Russian border (Statistics Finland 2020; Varjonen et al. 2017: 10-12, 15).

Perhaps due to the problematic history shared by the two countries, some Finns feel negatively towards Russia and the Russians living in Finland. Previous studies have found that Russian-speaking people might become victims of prejudice and even discrimination in Finland (e.g. Jaakkola 2000; Nshom 2017; Varjonen et al. 2017: 49-50, 93). For example, a job applicant with a Finnish name is called to an interview twice as often as an equally qualified applicant with a Russian name (Larja et al. 2012: 162-170). For this reason, 
personal name choices might have a remarkable influence on Russian-speaking people's lives. Should they choose a name that reflects their lingual and cultural background, or a name that merges them into the Finnish-speaking majority?

This study aims to provide a comprehensive overview of the given names of native Russian-speaking children born in Finland during the years 2000 2018. The major research questions are the following:

1) What kind of names do the Russian-speaking children receive? Are these names typical of Russian, Finnish, or some other culture?

2) Are there differences between girls' and boys' naming practices?

3) Are there differences in naming practices between the Russianspeaking citizens living in large cities and rural areas, or citizens living in different parts of Finland?

We start the article by introducing, in section 2, Finnish and Russian personal naming systems and related research. Data and methods used for this study are presented in section 3 . We then move on to the analysis in section 4 , beginning by examining the first given names and after that latter (second and third) given names of Russian-speaking children, finishing the analysis with the regional differences in naming. In sections 5 and 6, we round up the major results and present our conclusions.

\section{Background}

There is a lot in common between the personal naming systems in Finland and Russia but there are also remarkable differences. Historically, they both originate from the same Christian tradition of giving the names of Biblical characters and saints. However, due to the division of the Roman Empire and the Christian Church, the Christian tradition has developed in the two countries in different forms. The Russian naming system is mainly based on the Eastern European Greek-Orthodox tradition, whereas Finland, being a part of Sweden before 1809, was strongly influenced by the Western European Roman-Catholic and later Protestant culture (Singleton 1998; Leibring 2016: 203-204).

In contemporary Russia, the official personal name consists of one given name, ${ }^{1}$ a patronym formed from the person's father's name, and a surname, e.g. Vladimir Ivanovich ${ }^{2}$ Kartoshkin. Almost all given names are of Christian origin, semantically opaque. However, a few names from the pre-Christian era have survived, e.g. Slavic binomial names Jaroslav, Svyatoslav and Vladimir, and Russian adaptations of Scandinavian names: Igor, Oleg and Olga. The number of different given names is relatively low. According to Rylov (2006:

1 Since 2011, it has been legally possible to have more than one given name in Russia. The Russian Orthodox Church, however, still approves of only one given name, which probably has influenced the fact that the custom of multiple given names has not yet become widespread.

2 Ivanovich means 'son of Ivan'. The female version would be Ivanovna - 'daughter of Ivan'. 
$62,73)$, nowadays there are less than 450 given names at use in Russia. Instead of formal given names, short forms of names are very often used in informal situations, e.g. Katya for Ekaterina and Misha for Mihail, as well as more affectionate diminutives, e.g. Katyusha, Katenka, Katechka from Ekaterina (Superanskaya \& Suslova 2010).

In Finland, a person can have one, two or three given names, and a surname. ${ }^{3}$ Patronyms have not been officially used since the early 20 th century, and nowadays they are given rarely and only as a second or third given name. The majority of given names are names of Biblical characters or saints, mostly adapted to the Finnish phonetic system, e.g. Matti for Matteus and Kaisa for Katharina. Given names have been adopted from several sources, especially from Sweden, but also from Russia. There are also semantically transparent non-Christian names like Minttu 'mint', Tuuli 'wind', Valo 'light'. (See Ainiala et al. 2012: 157-201.) The number of different given names is considerably higher than in Russia. According to Kiviniemi (2006), Finns born during the 20th century have approximately 50,000 different given names.

Given names in Finland have been studied far and wide. Recent overviews of previous research have been made by Ainiala et al. (2012) and Saarelma-Paukkala (2017). Since the 1980s, research has largely been based on the population data collected by the Finnish Population Register Centre. These data present a comprehensive, reliable up-to-date picture of given names in Finland. Studies have mainly focused on the Finnish-speaking majority, but also other linguistic groups like Swedish, Sami and sign language speakers have also been studied (Ainiala et al. 2012: 197-201). Naming among the Russian-speaking population, however, has remained with relatively little attention. Saarelma-Paukkala (2017: 122) has listed the 10 most popular boys' and girls' names of Russian-speaking children in Finland in 2000-2016, but she does not present their counts or analyse them in detail. Eskola $(2013,2015)$ has studied name giving in bilingual Finnish-Russian families. There have also been a couple of studies about given names in Finnish Orthodox parishes (Kettunen 2008; Iljin 2013; see also Saarelma-Paukkala 2017: 112-115), where the percentage of Russian-speaking members is relatively high, even though the majority are Finnish-speaking members. ${ }^{4}$

The studies of given names in Russia have been carried out with different approaches. The establishment of the Russian personal naming system, the etymology, phonetics, formation, functions, semantics and usage of given names have been studied. The works of Superanskaya (1969), Nikonov (1970) and Superanskaya \& Suslova (2010) are considered to be fundamental in Russian

3 The Finnish name law (Etu-ja sukunimilaki, see References) was recently changed so that since the beginning of 2019, a person can have four given names. Because this change became valid only after our research period, it does not have any effect on this study.

4 In the Orthodox parish of Helsinki, 75\% of members are Finnish-speaking and 16\% Russian-speaking (Helsingin Ortodoksinen Seurakunta 2019). 
anthroponomastics. The current naming fashion has been studied most extensively by Vrublyovskaya (2017). The whole picture of given names in Russia is, however, not quite as comprehensive as in Finland. Scholars have been lacking nationwide population data, so the studies usually concentrate on a particular area of Russia.

In addition to Finnish and Russian anthroponomastics, this study contributes to the research of naming among linguistic minorities. This area of research has recently become a subject of notable interest among the onomastic scholars. The studies have focused especially on immigrant communities (e.g. Bramwell 2009, 2011; Bursell 2011; Morăraşu \& Drugă 2011; Garagulya 2012; Reisæter 2012; Pennesi 2016) and bilingual families (Aldrin 2009; Alhaug \& Saarelma 2009; Eskola 2015). These studies have mostly been conducted with interviews and surveys, therefore using relatively small datasets and mainly qualitative methods. This article approaches the theme from a somewhat different point of view, also using quantitative methods with the help of comprehensive population data.

\section{Data}

The main data of this study include the given names of all the children born in Finland between the years 2000-2018 and who have had Russian registered as their mother tongue. These data are collected by the Finnish Population Register Centre, and they include 9,459 children, approximately $0.9 \%$ of all children born in Finland during that period. In addition to all given names, the data include information on the children's gender and home municipality, therefore enabling us to examine regional and gender differences in naming practices. Of the children in the data, 4,804 (51\%) are boys and 4,655 (49\%) girls.

Even though these data represent the whole population comprehensively, they have some limitations. In the Finnish Population Register, only one mother tongue can be registered for a child. The data do not include any information on children's parents. Consequently, children registered as Russian-speaking include both monolingual children with two Russian-speaking parents and bilingual children with one Russian-speaking parent. Furthermore, the data do not include children whose mother tongue is Finnish but who also speak Russian.

In addition to the main data introduced above, two different comparison data sets are used in the study. They represent the given names of the Finnish-speaking children in Finland and the Russian-speaking children in Russia. The data of Finnish-speaking children are also obtained from the Finnish Population Register. They include given names of all the Finnish-speaking children born between 2000-2018, totalling almost 960,000 children. As for Russia, no such nationwide name statistics are available. Therefore, to represent current naming trends in Russia, we have used monthly lists of the 100 most popular girls' and boys' given names in Moscow. The lists are from January 2015 to September 2018, and they 
include given names of approximately 440,000 children. They are collected by the Population Register of Moscow and published open-access on the official Moscow website (City of Moscow 2019a, 2019b). Obviously, these data from one city cannot represent the whole country perfectly, but as its capital, with a population over 11 million inhabitants, it might be the best information available on the current naming trends in Russia. The Moscow data do not include information on children's mother tongue. We can presume that a vast majority of the children are Russian-speaking, but there are obviously speakers of other languages as well. ${ }^{5}$

Given names in the Moscow data are written in Cyrillic letters. This raises question of how they should be transliterated into Latin script, because the Finnish transliteration standard (SFS 4900) differs from the international one (ISO 9) to some extent. For example, the names Евгений, Максим and Михаил are transliterated as Jevgeni, Maksim and Mihail in Finnish but as Evgeny, Maxim and Mikhail in English. Obviously, Finnish-Russian name givers have to face the same problem if they choose a Russian name. Finnish transliterations seem to be more common in our data, but there are also plenty of international versions of the names.

One might also ask whether these different transliterations of Russian names really are different names, or are they only different forms of the same name. In the Moscow data, the counts of some similar names with different written forms, София and Софья (Sofia and Sofja) or Даниил, Данила and Данил (Daniil, Danila and Danil) for example, have been combined by the Moscow officials. In this article, however, we follow the Finnish anthroponomastic tradition of regarding each different written form as a different name (Kiviniemi 2006: 21-22; Ainiala et al. 2012: 172). We find this the most accurate solution, otherwise it would be more ambiguous regarding where the border between different names and different forms of the same name goes.

\section{Analysis}

\subsection{First given names}

Between the years 2000-2018, the Russian-speaking boys in the data received 872 and the girls 931 different first given names. These numbers can be considered rather high, as there are altogether fewer than 10,000 children in the data. Partially, the large number of different names can be explained by the various methods of transliteration, e.g. the Russian name Алексей appears in the data in the forms Aleksei, Aleksey, Aleksej, Alexei and Alexey. There are also plenty of compound names, combinations of two names joined by a hyphen (e.g. Anna-Maria). In total, there are 161 different compound names for girls and 120 for boys.

5 According to Koryakov (2017: 28), in 2010 in Moscow approximately 10.6 million persons had Russian as their mother tongue, which made up for more than $90 \%$ of the Moscow population at that time. 
Tables 1 and 2 show the 25 most common first given names for boys and girls in our data, including a comparison with the popularity of these names in Moscow and among the Finnish-speaking children in Finland. The exact counts for names with less than 10 bearers are not shown in Tables 1 and 2 for identity protection reasons. For the Moscow data, percentages cannot be given because we do not know the numbers of all children born in Moscow. The hyphen ("-") in the Tables means that the name does not appear in the monthly lists of 100 most popular names in Moscow. It might have been given in Moscow as well, but its quantity is presumably low.

Table 1: Most popular boys' first names among the Russian-speaking population in Finland

\begin{tabular}{|c|c|c|c|c|c|}
\hline Name & $\begin{array}{l}\text { Count in } \\
\text { Finland } \\
\text { (Russian- } \\
\text { speaking) }\end{array}$ & $\%$ & $\begin{array}{l}\text { Count in } \\
\text { Finland } \\
\text { (Finnish- } \\
\text { speaking) }\end{array}$ & $\%$ & $\begin{array}{l}\text { Count in } \\
\text { Moscow }\end{array}$ \\
\hline Daniel & 251 & 5.2 & 3,738 & 0.76 & 1,008 \\
\hline Nikita & 125 & 2.6 & 40 & 0.01 & 5,015 \\
\hline Anton & 108 & 2.2 & 2,876 & 0.59 & 1,105 \\
\hline Mark & 95 & 2.0 & 55 & 0.01 & 5,000 \\
\hline Alexander & 89 & 1.9 & 464 & 0.09 & see Aleksandr \\
\hline Maksim & 89 & 1.9 & 55 & 0.01 & 10,606 \\
\hline Leo & 76 & 1.6 & 5,004 & 1.0 & - \\
\hline Aleksi & 71 & 1.5 & 6,915 & 1.4 & - \\
\hline Daniil & 69 & 1.4 & 20 & 0.00 & 9,552 \\
\hline Mikael & 68 & 1.4 & 4,015 & 0.82 & - \\
\hline Aleksandr & 67 & 1.4 & 10 & 0.00 & 12,286 \\
\hline Maxim & 66 & 1.4 & 79 & 0.02 & see Maksim \\
\hline Ivan & 65 & 1.4 & 26 & 0.01 & 9,195 \\
\hline Denis & 58 & 1.2 & 19 & 0.00 & 2,123 \\
\hline Alex & 55 & 1.1 & 2,144 & 0.44 & - \\
\hline Timur & 54 & 1.1 & 17 & 0.00 & 2,577 \\
\hline Matvei & 53 & 1.1 & 13 & 0.00 & 5,446 \\
\hline Erik & 51 & 1.1 & 604 & 0.12 & - \\
\hline Kristian & 51 & 1.1 & 950 & 0.19 & - \\
\hline Kirill & 48 & 1.0 & 14 & 0.00 & 5,893 \\
\hline Martin & 48 & 1.0 & 164 & 0.03 & - \\
\hline Timofei & 45 & 0.94 & $<10$ & 0.00 & 5,160 \\
\hline Artur & 44 & 0.92 & 72 & 0.01 & 974 \\
\hline Miron & 41 & 0.85 & 15 & 0.00 & 2,041 \\
\hline Robert & 41 & 0.85 & 536 & 0.11 & 770 \\
\hline
\end{tabular}


Table 2: Most popular girls' first given names among the Russian-speaking population in Finland

\begin{tabular}{|c|c|c|c|c|c|}
\hline Name & $\begin{array}{l}\text { Count in } \\
\text { Finland } \\
\text { (Russian- } \\
\text { speaking) }\end{array}$ & $\%$ & $\begin{array}{l}\text { Count in } \\
\text { Finland } \\
\text { (Finnish- } \\
\text { speaking) }\end{array}$ & $\%$ & $\begin{array}{l}\text { Count in } \\
\text { Moscow }\end{array}$ \\
\hline Sofia & 285 & 6.1 & 6,077 & 1.3 & 6,983 \\
\hline Alisa & 159 & 3.4 & 2,726 & 0.8 & 8,172 \\
\hline Anna & 142 & 3.1 & 3,052 & 0.65 & 11,253 \\
\hline Maria & 135 & 2.9 & 1,614 & 0.34 & 9,812 \\
\hline Emilia & 127 & 2.7 & 6,033 & 1.3 & 1,177 \\
\hline Anastasia & 97 & 2.1 & 103 & 0.02 & 8,597 \\
\hline Milana & 89 & 1.9 & 201 & 0.04 & 4,094 \\
\hline$E v a$ & 82 & 1.8 & 402 & 0.09 & 5,016 \\
\hline Elina & 72 & 1.5 & 1977 & 0.42 & 850 \\
\hline Diana & 71 & 1.5 & 174 & 0.04 & 1,908 \\
\hline Alina & 67 & 1.4 & 1,947 & 0.42 & 2,238 \\
\hline Julia & 66 & 1.4 & 3,961 & 0.85 & 1,843 \\
\hline Aleksandra & 62 & 1.3 & 363 & 0.08 & see Alexandra \\
\hline Polina & 57 & 1.2 & $<10$ & 0.00 & 7,803 \\
\hline Veronika & 54 & 1.2 & 53 & 0.01 & 4,844 \\
\hline Kristina & 53 & 1.1 & 70 & 0.01 & 2,174 \\
\hline Laura & 53 & 1.1 & 3,513 & 0.75 & - \\
\hline Olivia & 52 & 1.1 & 3,601 & 0.77 & 519 \\
\hline Darja & 47 & 1.0 & $<10$ & 0.00 & 6,875 \\
\hline Arina & 45 & 0.97 & $<10$ & 0.00 & 5,593 \\
\hline Elizaveta & 40 & 0.86 & $<10$ & 0.00 & 7,369 \\
\hline Ekaterina & 39 & 0.84 & $<10$ & 0.00 & 6,465 \\
\hline Alexandra & 33 & 0.71 & 448 & 0.10 & 7,002 \\
\hline Vera & 33 & 0.71 & 481 & 0.10 & 2,870 \\
\hline Emma & 32 & 0.69 & 7,366 & 1.6 & 156 \\
\hline
\end{tabular}

The most common first given names for boys and girls were, quite distinctly, Daniel and Sofia. During the research period, 251 boys (5.2\% of all boys) were named Daniel and 285 girls (6.1\% of girls) Sofia. These percentages can be considered high because the most common first given names for the Finnishspeaking children, Eetu and Emma, were given to $1.6 \%$ of all boys and $1.6 \%$ of all girls during the same period. It must be noted, however, that the second-most popular names for Russian-speaking children, Nikita and Alisa, are considerably less popular, being given to $2.6 \%$ of boys and $3.4 \%$ of girls. Nevertheless, the higher popularity of the most popular names among the Russian-speaking children might reveal the influence of Russian naming culture, in which the name stock is narrower and having the same names is more common than in Finland. 
The popularity of Daniel might be a little surprising, as Russians usually prefer the forms Daniil, Danil and Danila. Those names are aggregated in the Moscow data (which might mean that the Moscow officials consider them as a same name), being 6th on the list of most popular names with 9,552 bearers. Daniel, the international form of the name, is only 57th on that list with 1,008 bearers. In addition to Daniel, the top five of Russian-speaking boys' names include Nikita, Anton, Mark and Alexander. Nikita is a common name in Russia but not outside Slavic countries. Anton has been somewhat popular in both Finland and Russia during the 21 st century. Mark has traditionally been used in English-speaking countries, whereas in Russia it has become popular only recently. Alexander is an internationally used form of the name that is often spelled as Aleksander, Aleksandr, or Alexandr in the Russian context (e.g. in the Moscow data they are all gathered together).

The five most common girls' names might not be very surprising. Anna and Maria have been among the most common names across the Christian world for centuries, still retaining their popularity. Sofia has been highly popular during the 21st century, not only in Finland and Russia but also in several other countries of Europe (Leibring 2016: 211). Alisa is also usual in both Finland and Russia, even though not that popular in other countries. Emilia has been very popular in Finland in the last few decades, whereas in Russian it became widely used only recently.

Tables 1 and 2 would look somewhat different if different transliterated forms of the same Russian names were counted together. For example, Alexander, Aleksandr, Aleksander and Alexandr would make a total of 196, becoming the second-most popular boys' name. The names Maksim and Maxim are given to 155 boys, thus rising to third place on the list. Also, the names Aleksei (62), Mihail (59) and Artem (57) would appear in the list. The table of girls' most popular names would change less, but Aleksandra (95) and Darja (63) would be higher, and Ksenia (44) would make it to the list.

Looking at the most common names, however, does not tell the whole story of the names of the Russian-speaking children. In order to extend the view on the data, we have classified the 100 most common boys' and girls' names ${ }^{6}$ into five categories:

1. Finnish names. These names are common in Finland and possibly also in some neighbouring countries such as Sweden and Estonia, but not in Russia or other parts of Europe. E.g. Aleksi, Elias, Timo; Anita, Jaana, Maija.

2. Russian names. These names are common in Russia and they might appear in other Slavic countries as well, but they are not used in Finland

6 The analysis is limited to the 100 most common names, as the counts for the remaining names are so small that they do not have a notable statistical significance. Including them would have caused us considerable additional work and would probably not have changed the results. 
or Western Europe. E.g. Aleksandr, Kirill, Nikita; Anastasia, Ekaterina, Polina.

3. International names. These names are common in several countries. E.g. Alex, David, Robert; Anna, Maria, Sofia.

4. Both Finnish and Russian names. These names are common in both Finland and Russia, but not in other countries. For this reason, they are separated from international names. E.g. Anton; Alisa, Alina.

5. Names of Russian minorities. These names are common in Russia but only among linguistic minorities, e.g. Bashkirs and Tatars. They are usually perceived as non-Russian names by Russians. E.g. Damir, Ruslan, Timur; Darina, Karina.

The categorisation is mainly based on the commonness of the names in different countries. As for Finland and Russia, we have used our own datasets to support our interpretations, whereas, for other countries, we have combined several sources, such as the given name dictionary of Hanks et al. (2006) and open-access online national lists and statistics for popular names (e.g. ONS, SSA, Baby Name Wizard; see References). We want to emphasize that despite the help of these sources, not all the names were easy to place in these categories. Nevertheless, we find the categorisation necessary in order to make a comprehensive overview of the data.

Table 3 shows how the 100 most popular boys' and girls' names are distributed amongst these five categories. The largest number of boys' names are Russian, but the numbers or international and Finnish names are also considerable. Amongst girls' names, 40 of the 100 most popular names are also Russian. However, the total number of girls that have received an international name is distinctly larger, meaning that the international names are especially at the top of the popularity lists. The difference in boys' and girls' naming is anticipated. Previous studies have also shown that, at least in Finland, name choices for boys are usually more traditional and conservative than for girls (SaarelmaPaukkala 2017: 65), even though the differences are quite moderate.

Table 3: Distribution of the 100 most popular boys' and girls' first given names among the Russian-speaking population in Finland

\begin{tabular}{|r||c|c|c||c|c|c|}
\cline { 2 - 7 } \multicolumn{1}{c|}{} & \multicolumn{3}{c||}{ boys } & \multicolumn{3}{c|}{ girls } \\
\hline $\begin{array}{r}\text { Category of } \\
\text { the name }\end{array}$ & $\begin{array}{c}\text { Count } \\
(\mathbf{N = 1 0 0 )}\end{array}$ & $\begin{array}{c}\text { Total } \\
\text { count } \\
(\mathbf{N = 4 , 8 0 4 )}\end{array}$ & $\mathbf{\%}$ & $\begin{array}{c}\text { Count } \\
(\mathbf{N = 1 0 0 )}\end{array}$ & $\begin{array}{c}\text { Total } \\
\text { count } \\
(\mathbf{N = 4 , 6 5 5 )}\end{array}$ & \% \\
\hline Russian & 46 & 1,388 & 42.4 & 38 & 996 & 30.9 \\
\hline International & 29 & 1,033 & 31.6 & 32 & 1,409 & 43.7 \\
\hline Finnish & 21 & 664 & 20.3 & 24 & 482 & 15.0 \\
\hline $\begin{array}{r}\text { Both Russian } \\
\text { and Finnish }\end{array}$ & 1 & 108 & 3.3 & 4 & 299 & 9.3 \\
\hline Russian minorities & 3 & 78 & 2.4 & 2 & 38 & 1.2 \\
\hline Altogether & $\mathbf{1 0 0}$ & $\mathbf{3 , 2 7 1}$ & $\mathbf{1 0 0}$ & $\mathbf{1 0 0}$ & $\mathbf{3 , 2 2 4}$ & $\mathbf{1 0 0}$ \\
\hline
\end{tabular}


As mentioned in section 3, Russian names can be transliterated into Latin script in either the Finnish or international way. Overall, it seems that Finnish transliterations are more common in the data, e.g. Maksim, Matvei, Aleksandra and Viktoria are more usual than Maxim, Matvey, Alexandra and Victoria. There are still a few exceptions to that, e.g. Egor and Elena are more popular than Jegor and Jelena.

It is important to examine not only the names in the popularity lists but also the names that are lacking from them. Several very common Russian names have been given quite rarely to Finnish-Russian children, e.g. boys' names Vladimir (53rd place on the list), Sergei (72nd), Dmitri (93rd), and Igor (97th), and girls' names Olga (79th), Irina (88th), Natalia (120th) and Tatjana (187th). This could be partly due to the changes in naming fashion. Some of these names are not very high in the Moscow data either (Dmitri 7th, Vladimir 18th, Sergei 23rd, Igor 48th; Olga 29th, Tatjana 35th, Irina 43rd, Natalia $62 \mathrm{nd}$ ). During the 2010s in Russia, it has become fashionable to give children old Russian names that have not been popular for a long while, e.g. Matvei, Prohor, Uljana, Miroslava, Serafima and Vasilisa (Vrublyovskaya 2017: 131132). A similar revival trend has been recognised in Finland as well (Ainiala et al. 2012: 185). According to these results, the Finnish-Russian population seem to be aware of Russian naming trends. This is probably because many Finnish-Russians follow and receive influences from the Russian media and often visit Russia. The same applies to the Swedish-speaking population in Finland (Saarelma-Paukkala 2017: 105).

Popularity lists of Russian-speaking children also lack some of the most fashionable names among the Finnish-speaking Finns in the 21 st century, e.g. Eetu, Onni and Veeti for boys (1st, 4th and 5th on the list of Finnish-speaking children) or Aino, Ella and Venla for girls (2nd, 3rd and 4th). These are traditional Finnish names that do not have similar equivalents in Russia, and some of them have certain cultural significance for Finns. ${ }^{7}$ The name's phonetics might also explain whether the Russian-speaking population uses them or not. In Finland, both boys' and girls' names might end with various different phones, whereas in Russia girls' names usually end with $-a$ and boys' names with a consonant or $-y$ (as in Andrey). Consequently, Russian-speaking children are rarely given names ending with $-e,-o$ or $-u$. For a Russian speaker, these endings seem strange, since in Russian they belong only to inanimate, neuter nouns. The same applies to names with long vowels or consonants (e.g. Eetu and Ella), as these do not exist in Russian.

7 Aino appears in the Finnish national epic Kalevala and Venla in Seitsemän veljestä, the first novel in Finnish. Onni is also an appellative, meaning 'happiness, bliss, luck, fortune'. 


\subsection{Latter given names}

According to the Finnish name law, a person can have one, two or three given names (see Etu- ja sukunimilaki). ${ }^{8}$ Nowadays, nearly all Finns receive more than one given name: $52 \%$ of Finnish-speaking children born in Finland during 2000-2018 received two, 46\% three and only $2 \%$ one given name. However, the situation with Russian-speaking children is quite different. During the same period, $65 \%$ of them received one given name, $29 \%$ two and $6 \%$ three given names. Consequently, the Finnish-Russian population seems to follow Russian rather than Finnish naming traditions in this matter. The result is rather different to bilingual Finnish-Russian families, where only 13\% of children receive one, $70 \%$ two and 17\% three given names (Eskola 2013, 2015).

In Finland, latter (second and third) given names usually differ from first given names by both their structure and functions. For rhythmic reasons, they are mostly longer than the first given names, which most often consist of two syllables, while latter given names have three syllables. Latter given names are seldom used in daily life, so they are in a way "hidden" from the public eye. Therefore, they can include values and meanings that one does want to carry within but not to display all the time. Naming fashion has little influence on their popularity, so the most popular names change very slowly. Juhani and Maria have remained as the most popular latter given names for boys and girls throughout most of the 20th and 21st century (Ainiala et al. 2012: 173-176; Saarelma-Paukkala 2017: 37-40, 48, 88-91).

Table 4: Most popular boys' latter given names among the Russian-speaking population in Finland

\begin{tabular}{|c|c|c|c|c|}
\hline Name & $\begin{array}{c}\text { Count in } \\
\text { Finland } \\
\text { (Russian- } \\
\text { speaking) }\end{array}$ & $\%$ & $\begin{array}{c}\text { Count in } \\
\text { Finland } \\
\text { (Finnish- } \\
\text { speaking) }\end{array}$ & $\mathbf{\%}$ \\
\hline Mikael & 96 & 2.0 & 23,846 & 4.9 \\
\hline Kristian & 71 & 1.5 & 12,780 & 2.6 \\
\hline Daniel & 65 & 1.4 & 3,557 & 0.72 \\
\hline Alexander & 59 & 1.2 & 3,274 & 0.67 \\
\hline Aleksi & 45 & 0.9 & 752 & 0.15 \\
\hline Elias & 38 & 0.8 & 8,596 & 1.8 \\
\hline Oliver & 32 & 0.7 & 8,261 & 1.7 \\
\hline Aleksandr & 24 & 0.5 & 48 & 0.01 \\
\hline Matias & 23 & 0.5 & 17,420 & 3.6 \\
\hline Leo & 22 & 0.5 & 2,093 & 0.43 \\
\hline
\end{tabular}

\footnotetext{
${ }^{8}$ See footnote 3 .
} 
Table 5: Most popular girls' latter given names among the Russian-speaking population in Finland

\begin{tabular}{|c|c|c|c|c|}
\hline Name & $\begin{array}{c}\text { Count in } \\
\text { Finland } \\
\text { (Russian- } \\
\text { speaking) }\end{array}$ & $\%$ & $\begin{array}{c}\text { Count in } \\
\text { Finland } \\
\text { (Finnish- } \\
\text { speaking) }\end{array}$ & $\mathbf{\%}$ \\
\hline Maria & 132 & 2.7 & 39,953 & 8.5 \\
\hline Sofia & 104 & 2.2 & 25,100 & 5.4 \\
\hline Aleksandra & 57 & 1.2 & 8,571 & 1.8 \\
\hline Emilia & 55 & 1.1 & 25,275 & 5.4 \\
\hline Alexandra & 42 & 0.87 & 5,562 & 1.2 \\
\hline Victoria & 38 & 0.79 & 663 & 0.14 \\
\hline Anastasia & 36 & 0.75 & 733 & 0.16 \\
\hline Anna & 32 & 0.67 & 5,713 & 1.2 \\
\hline Olivia & 32 & 0.67 & 11,920 & 2.5 \\
\hline Katariina & 29 & 0.60 & 10,562 & 2.3 \\
\hline
\end{tabular}

Altogether, Russian-speaking boys received 1,884 latter given names and girls 1,920. These included 605 different names for boys and 581 for girls. The variety of different names is thus very broad. Tables 4 and 5 show the 10 most popular boys' and girls' latter given names, with comparison to their popularity as latter names for the Finnish-speaking children. As seen in the Tables, the most popular latter given names are Mikael and Maria, which are very popular latter given names for Finnish-speaking children as well. Daniel and Sofia, the most popular first given names, are often given as latter names as well. It is also worth noticing that Juhani, the most popular boys' latter given name in Finland, is only at 21 st place on the list.

We have divided the 50 most popular boys' and girls' latter given names into categories, using the categorisation presented in section 4.1. Of boys' names, 24 are Finnish, 16 international, and 10 Russian. Of girls' names, 22 are international, 18 Finnish, 8 Russian, and 2 both Finnish and Russian. These results are notably different from those of first given names. The number of Finnish names as latter given names is remarkably high, and the number of Russian names low, for both boys and girls. This is probably because the practice of giving latter given names is a Finnish rather than Russian tradition. Moreover, latter names might be given especially in bilingual families, so that the first given name represents Russian and the latter given name(s) Finnish culture.

Last given names of Russian-speaking children also include some patronyms formed with Russian suffixes, e.g. Mihailovich, Pavlovich; Aleksandrovna, Ivanovna. However, this is quite a rare phenomenon in our data. Altogether, Russian-speaking boys have 38 different patronyms with -ovich, -evich or -jevich suffixes, and girls have 29 different patronyms with -ovna, -jevna suffixes. These patronyms are based not only on Russian but also on Finnish and other male 
names. The data also include seven Finnish-type patronyms, e.g. Sergeinpoika 'son of Sergei', Ivanintytär 'daughter of Ivan'. '

\subsection{Regional variation}

Finland is a sparsely inhabited country with long distances between cities. Therefore, cultural differences between the regions of Finland have been quite distinct. This applies also to personal names. Previous studies have shown that there are notable regional differences in naming conventions, even though they have diminished during the last century. Naming fashion and new innovations usually spread from the large cities of Southern Finland to the rest of the country (e.g. Ainiala et al. 2012: 183; Saarelma-Paukkala 2017: 72-77).

Our data include the information of each child's home municipality. In order to examine regional variation, we have categorised the municipalities in two different ways, that is, on the basis of geographical location and municipality size. Based on geographical location, municipalities were divided into three groups: Southern, Western, and Eastern Finland. ${ }^{10}$ Based on the municipality size, they were divided into two groups: large cities $(100,000$ or more inhabitants) and smaller towns (less than 100,000 inhabitants). ${ }^{11}$

We have formed lists of the 50 most common girls' and boys' first given names in the different regions described above. Those names are, once again, divided into the categories of Russian, Finnish, international, both Russian and Finnish, and Russian minority names. The results of these categorizations are presented in Tables 6 and 7. As seen in the Tables, international names are given most often - and Finnish names least often - in Southern Finland and in large cities. Russian names are given for boys especially in Eastern Finland and smaller towns, whereas for girls, on the contrary, in Southern Finland and in large cities.

9 The patronyms in this chapter have been made up by authors, resembling the real ones in our data. All the patronyms were given to less than 10 children, so they cannot be revealed for privacy protection reasons.

10 In our classification, Southern Finland comprises the region of Uusimaa, Eastern Finland comprises the regions of Kymenlaakso, Northern and Southern Karelia, Northern and Southern Savonia and Kainuu, and Western Finland comprises the remaining regions. Uusimaa stands alone as Southern Finland so that convenient statistical groups can be formed; 50\% of Russian-speaking children were born there between 2000-2018. For the regions of Finland, see for example www.maanmittauslaitos.fi/sites/maanmittauslaitos.fi/ files/attachments/2019/01/tilaston_pohjakartta_a4.pdf (accessed 2020-01-23).

11 According to this classification, 9 (3\%) of Finland's municipalities are large cities and the remaining 302 (97\%) are smaller towns. 
Table 6: Distribution of the 50 most popular boys' and girls' first given names in Southern, Eastern and Western Finland

\begin{tabular}{|r||c|c|c||c|c|c|}
\cline { 2 - 7 } \multicolumn{1}{c|}{} & \multicolumn{3}{c||}{ boys } & \multicolumn{3}{c|}{ girls } \\
\hline $\begin{array}{r}\text { Category } \\
\text { of the name }\end{array}$ & $\begin{array}{c}\text { Southern } \\
\text { Finland }\end{array}$ & $\begin{array}{c}\text { Eastern } \\
\text { Finland }\end{array}$ & $\begin{array}{c}\text { Western } \\
\text { Finland }\end{array}$ & $\begin{array}{c}\text { Southern } \\
\text { Finland }\end{array}$ & $\begin{array}{c}\text { Eastern } \\
\text { Finland }\end{array}$ & $\begin{array}{c}\text { Western } \\
\text { Finland }\end{array}$ \\
\hline Russian & 38.7 & 52.1 & 37.0 & 32.5 & 25.0 & 28.5 \\
\hline International & 35.2 & 20.7 & 29.6 & 49.5 & 46.6 & 45.3 \\
\hline Finnish & 19.2 & 22.1 & 27.6 & 6.2 & 16.4 & 15.7 \\
\hline $\begin{array}{r}\text { Both Russian } \\
\text { and Finnish }\end{array}$ & 4.2 & 3.6 & 4.3 & 11.7 & 10.5 & 9.4 \\
\hline Russian minorities & 2.7 & 1.5 & 1.4 & - & 1.5 & 1.0 \\
\hline
\end{tabular}

Table 7: Distribution of the 50 most popular boys' and girls' names in larger and smaller cities

\begin{tabular}{|r||c|c||c|c|}
\cline { 2 - 4 } \multicolumn{1}{||}{} & \multicolumn{2}{c||}{ boys } & \multicolumn{2}{c|}{ girls } \\
\hline Category of the name & $\begin{array}{c}\text { Large } \\
\text { cities }\end{array}$ & $\begin{array}{c}\text { Smaller } \\
\text { towns }\end{array}$ & $\begin{array}{c}\text { Large } \\
\text { cities }\end{array}$ & $\begin{array}{c}\text { Smaller } \\
\text { towns }\end{array}$ \\
\hline Russian & 39.3 & 46.6 & 30.4 & 26.7 \\
\hline International & 33.1 & 25.8 & 48.3 & 46.4 \\
\hline Finnish & 20.7 & 22.6 & 10.2 & 14.5 \\
\hline Both Russian and Finnish & 4.6 & 3.4 & 11.1 & 10.8 \\
\hline Russian minorities & 2.4 & 1.6 & - & 1.5 \\
\hline
\end{tabular}

On examining more closely the regional lists of most common names, it can be noticed that Daniil is one of the most common names in Eastern Finland but quite rare in other areas. The international name Alexander is popular especially in the large cities of Southern Finland. In Western Finland, the Swedish influence also can be noticed, because the Scandinavian name Erik is quite popular there. When it comes to girls' names, the regional differences seem to be less visible. Traditional Russian names like Aleksandra and Polina seem to be most common in Southern Finland.

The regional differences, especially the tendency of giving traditional Russian names in Eastern and Southern Finland, is probably connected to the whereabouts of the Russian-speaking population. A great majority of Russianspeaking citizens live in large cities or in Eastern Finland near the Russian border. $^{12}$ This leads to the conclusion that in rural areas as well as in Western and Northern Finland, where the Russian-speaking population is quite small, they feel a greater need of integrating into the Finnish-speaking majority, and

$1262 \%$ of the children in our data were born in large cities and $38 \%$ in smaller towns, whereas only $39 \%$ of the whole Finnish population live in large cities (Statistics Finland 2020). See also Varjonen et al. (2017: 10-12). 
therefore adapt their names to the Finnish system more markedly.

It should be mentioned, however, that the differences in the naming practices of Russian-speaking citizens between the regions of Finland are quite moderate. Daniel and Sofia are the most popular given names in all regions of Finland. As the amount of data is relatively small (less than 10,000 children), one should be careful when making generalisations.

\section{Discussion}

As we have seen in section 4, given names of the Russian-speaking children in Finland include a great deal of both Russian and Finnish names as well as international names that are used in similar forms in several countries. Russian names are given most often to boys, whereas girls receive more international than Russian names. Two out of three Finnish-Russian children receive only one given name, in line with the Russian personal naming tradition. However, the latter given names include many more Finnish than Russian names. In large cities and Eastern Finland, where the density of Russian-speaking population is highest, Russian names are given more often than elsewhere. Overall, the given names of Russian-speaking children in Finland are a multifaceted mixture of different naming traditions and fashions.

The datasets we have used do not include any information on the parents of these Russian-speaking children. But could their name choices tell us something? The large number of Russian names, as well as the low number of children who receive two or three given names, might imply that many parents want to stick with the Russian naming tradition. Giving international names (e.g. the most popular names Daniel and Sofia), on the other hand, can be seen especially as a safe and practical choice. They are recognised as personal names in both Finland, Russia and other countries, and they do not reveal the cultural background of their bearers. Finnish names are given particularly in areas with a small Russian-speaking population, which might suggest that these parents feel the greatest need to integrate into the Finnish-speaking majority. The lack of some of the most traditional and well-known Russian names, such as Vladimir, Sergei, Olga or Tatjana, might convey that the parents do not especially want to highlight the Russian background of their children. But on the other hand, the lack of some very fashionable Finnish names, such as Eetu, Onni, Aino or Venla, implies that they do not want to adopt names that would be completely unfamiliar to the Russian naming tradition. These findings match the results of Eskola $(2013,2015)$, who has found that bilingual Finnish-Russian parents want to give names that work well in both languages.

Overall, the Russian culture seems to influence name giving somewhat more strongly than the Finnish culture. This is quite understandable, because personal naming practices are often based on long cultural traditions. The great 
majority of the Russian-speaking population have been living in Finland for a couple of decades at most, and therefore many of them presumably still have a strong connection with the Russian culture. Bramwell (2009) and Reisæter (2012) have also found that immigrants often carry on the naming traditions of their old homeland.

Above all, the various naming choices tell us that the Russian-speaking minority in Finland is a diverse group of people. Some of them want to preserve their cultural background, whereas others try to integrate more into the culture of their new homeland. The data also include bilingual families who differ from the monolingual Russian-speaking families, and who often combine the two naming traditions (Eskola 2013, 2015).

\section{Conclusion}

Due to globalisation and increasing migration, different linguistic and ethnic minorities are growing around the world. In different cultures, personal names have distinct characteristics, so they often preserve and reveal the linguistic and cultural background of their bearers. This makes studying personal names increasingly relevant and important.

In this study, we have examined the given names of the Russian-speaking minority in Finland, based on the Finnish population register data. These kinds of data give a comprehensive overview of the topic but cannot answer all the questions. It would be interesting to know in more detail how parents representing linguistic minorities choose names for their children, and what motivations lie behind their choices. Answering these questions, however, would require the use of surveys or interviews, so it remains as a task for possible future studies.

\section{References}

Ainiala, Terhi \& Saarelma, Minna \& Sjöblom, Paula. 2012. Names in Focus. An introduction to Finnish onomastics. Helsinki: Finnish Literature Society. (https://www.oapen.org/search?identifier=617174) (Accessed 2019-11-11.) (Studia Fennica Linguistica.)

Aldrin, Emilia. 2009. The choice of first names as a social resource and act of identity among multilingual families in contemporary Sweden. In Ahrens, Wolfgang \& Embleton, Sheila \& Lapierre, André (eds.), Names in multi-lingual, multi-cultural and multi-ethnic contact. Proceedings of the 23rd International Congress of Onomastic Sciences, 86-92. Toronto: York University.

Aldrin, Emilia. 2017. Assessing names? Effects of name-based stereotypes on teachers' evaluations of pupils' texts. Names 65(1), 3-14. 
Alford, Richard D. 1988. Naming and identity. A cross-cultural study of personal naming practices. New Haven, CT: HRAF.

Alhaug, Gulbrand \& Saarelma, Minna. 2009. Namn på barn i Noreg (fødd 1990-2006) med finske eller finsk-norske foreldre [Names of children in Norway (born 1990-2006) with Finnish or Finnish-Norwegian parents]. In Mattoflk, Leila \& Ainiala, Terhi (eds.), Namn och kulturella kontakter. Handlingar från NORNA:s 37 symposium i Hapsal 22-25 maj 2008 [Names and cultural contacts. Proceedings of the 37th NORNAsymposium in Haapsalu 22-25 May 2008], 85-109. Helsingfors: Forskningscentralen för de inhemska språken. (NORNA-rapporter 85.)

Baby Name Wizard. (https://www.babynamewizard.com/) (Accessed 2020-01-23.) Bramwell, Ellen S. 2009. Names in multi-cultural Scotland. In Ahrens, Wolfgang \& Embleton, Sheila \& Lapierre, André (eds.), Names in multilingual, multi-cultural and multi-ethnic contact. Proceedings of the 23rd International Congress of Onomastic Sciences, 158-163. Toronto: York University.

Bramwell, Ellen S. 2011. Naming and transplanted traditions: Change and continuity in Glasgow's Pakistani Muslim community. Onoma 46, 29-51.

Bursell, Moa. 2011. Name change and destigmatization among Middle Eastern immigrants in Sweden. Ethnic and Racial Studies 35(3), 471-487.

City of Moscow 2019a = Сведения о наиболее популярных женских именах среди новорожденных [Information about the most popular female names among newborns]. Official website of the city of Moscow. (https://data.mos. ru/opendata/7704111479-svedeniya-o-naibolee-populyarnyh-jenskih-imenahsredi-novorojdennyh) (Accessed 2019-12-30.)

City of Moscow 2019b = Сведения о наиболее популярных мужских именах среди новорожденных [Information about the most popular male names among newborns]. Official website of the city of Moscow. (https://data.mos. ru/opendata/svedeniya-o-naibolee-populyarnyh-mujskih-imenah-sredinovorojdennyh) (Accessed 2019-12-30.)

Eskola, Ksenia. 2013. Suomalais-venäläisten lasten etunimet: valintaperusteet ja rakenne [Given names of Finnish-Russian children: Principles and structure]. University of Turku, Department of Finnish language. (Master's thesis.)

Eskola, Ksenia. 2015. Kansainvälinen, suomalainen vai venäläinen? Nimivalinnat Suomen 2000-luvun suomalais-venäläisissä perheissä [International, Finnish or Russian? Name choices of Finnish-Russian families in 21st-century Finland]. Sananjalka 57, 86-105.

Etu- ja sukunimilaki. 19.12.2017/946. (https://www.finlex.fi/fi/laki/ ajantasa/2017/20170946) (Accessed 2019-12-11.)

Garagulya, Sergey I. 2012 = Гарагуля, С. И. 2012. Языковая личность. Индивид и его имя в иноязычной среде [Linguistic personality. A person and his name in a foreign language environment]. Москва: Издательский дом Либриком. 
Gerritzen, Doreen. 2006. Naming children in a globalizing world. Acta Onomastica XLVII, 177-184.

Hanks, Patrick \& Hardcastle, Kate \& Hodges, Flavia. 2006. A dictionary of first names, 2nd edition. Oxford, New York: Oxford University Press.

Helsingin Ortodoksinen Seurakunta. 2019. Vuosikertomus 2018 [Annual report 2018]. (https://www.hos.fi/wp-content/uploads/2019/08/Vuosikertomus2018 valtuusto-hyva\%CC\%88ksynyt-23.5.2019.pdf) (Accessed 2020$01-0 \overline{7}$.)

Iljin, Outi. 2013. Perinne ja muuttuvat nimet. Helsingin ortodoksisessa seurakunnassa vuosina 2000-2009 kastettujen lasten ensinimet [Tradition and changing names. Given names of children baptized in the Orthodox parish of Helsinki in 2000-2009]. University of Helsinki, Department of Finnish and Finno-Ugrian languages. (Master's thesis.)

Jaakkola, Magdalena. 2000. Finnish Attitudes towards immigrants in 19871999. Finnish Yearbook of Population Research 36, 129-161. (https://journal.fi/fypr/article/view/44951) (Accessed 2019-11-25.)

Kettunen, Eija-Helena. 2008. Etunimiä ja nimikäytäntöä Joensuun ortodoksisessa seurakunnassa [Given names and naming practices in the Orthodox parish of Joensuu]. University of Joensuu, Department of Finnish language. (http://epublications.uef.fi/pub/URN NBN fi joy-20080012/URN NBN fi_joy-20080012.pdf) (Accessed 2019-11-11.) (Master's thesis.)

Kiviniemi, Eero. 2006. Suomalaisten etunimet [Given names in Finland]. Helsinki: Suomalaisen Kirjallisuuden Seura.

Koryakov, Yury B. 2017 = Коряков Ю. Б. 2017. Языки Москвы по данным переписи 2010 года [Languages of Moscow according to population census 2010]. Родной язык 2(7), 24-44.

Larja, Liisa \& Warius, Johanna \& Sundbäck, Liselott \& Liebkind, Karmela \& Kandolin, Irja \& Jasinskaja-Lahti, Inga. 2012. Discrimination in the Finnish labor market. An overview and a field experiment on recruitment. (https://yhdenvertaisuus.fi/documents/5232670/5376058/Discrimination $+\mathrm{i}$ $\mathrm{n}+$ the+Finnish+Labour+Market) (Accessed 2020-01-06.) (Publications of the Ministry of Employment and the Economy. Employment and Entrepreneurship 16/2012.)

Lawson, Edwin D. 2016. Personal naming systems. In Hough, Carole \& Izdebska, Daria (eds.) The Oxford handbook of names and naming, 169198. Oxford: Oxford University Press.

Leibring, Katharina. 2016. Given names in European naming systems. In Hough, Carole \& Izdebska, Daria (eds.) The Oxford handbook of names and naming, 199-213. Oxford: Oxford University Press.

Morăraşu, Nadia Nicoleta \& Drugă, Luminiţa. 2011. Projecting the ethnic identity of Romanian Gypsies/Roma through contemporary first namegiving practices. Onoma 46, 77-96. 
Nikonov, Vladimir A. $1970=$ Никонов В. А. (ed.). 1970. Личные имена 8 прошлом, настоящем и будущем [Personal names in the past, present and future]. Москва: Наука.

Nshom, Elvis. 2017. Perceived threat and prejudice towards immigrants and Russian minorities living in Finland. Jyväskylä. (http://urn.fi/URN:ISBN: 978-951-39-6972-1) (Accessed 2020-01-23.) (Jyväskylä Studies in Humanities 306.)

ONS = Office for National Statistics. Baby Name Explorer. (https://www.ons. gov.uk/peoplepopulationandcommunity/birthsdeathsandmarriages/livebirt hs/articles/babynamesexplorer/2019-06-07) (Accessed 2020-01-23.)

Pennesi, Karen. 2016. "They can learn to say my name": Redistributing responsibility for integrating immigrants to Canada. Anthropologica $58(1), 46-59$.

Reisæter, Guro. 2012. Immigrants in Norway and their choice of names: continuation or adaption? In Helleland, Botolv \& Ore, Christian-Emil \& Wikstrøm, Solveig (eds.), Names and identities, 223-234. Oslo: University of Oslo. (Oslo Studies in Language 4 (2).)

Rylov, Yury A. 2006 = Рылов Ю. А. 2006. Имена собственные в европейских языках. Романская и русская антропонимика [Personal names in European languages. Romance and Russian anthroponomastics]. Москва: АCT.

Saarelma-Paukkala, Minna. 2017. Etunimikirja: Suomalaiset nimitrendit 2000-luvulla [Given name book: Finnish name trends in the 21st century]. Helsinki: Suomalaisen Kirjallisuuden Seura.

Singleton, Frederick B. 1998. A short history of Finland, 2nd edition. Anthony F. Upton (ed.). Cambridge University Press.

SSA = Social Security Administration. Popular Baby Names. (https://www.ssa. gov/oact/babynames/) (Accessed 2020-01-23.)

Statistics Finland. 2020. Population. (www.tilastokeskus.fi/tup/suoluk/ suoluk_vaesto_en.html) (Accessed 2020-01-06.)

Superanskaya, Aleksandra V. 1969 = Суперанская A. B. 1969. Структура имени собственного. Фонология и морфология [Structure of a personal name. Phonology and morphology]. Москва: Наука.

Superanskaya, Aleksandra V. \& Suslova, Anna V. $2010=$ Суперанская A. B. \& Суслова А. В. 2010. О русских именах [About Russian names], 5-е издание. Санкт-Петербург: Азбука.

Varjonen, Sirkku \& Zamiatin, Aleksandr \& Rinas, Marina. 2017. Russians in Finland here and now. Statistics, surveys, organisation field. Cultura Foundation. (https://culturas.fi/wp-content/uploads/2018/08/Venajankielisetsuomessa-ENG.pdf) (Accessed 2020-01-08.)

Vrublyovskaya, Oksana V. 2017 = Врублевская О. В. 2017. Языковая мода в русской ономастике [Name fashion in Russian onomastics]. Волгоград. (Doctoral dissertation.) 